\title{
Biosynthesis of tetrahydrofuran lignans in Virola surinamensis
}

\author{
Norberto Peporine Lopes ${ }^{1 *}$, Massayoshi Yoshida ${ }^{2,3}$, Massuo Jorge Kato ${ }^{3}$ \\ ${ }^{1}$ Faculdade de Ciências Farmacêuticas de Ribeirão Preto, Universidade de São Paulo Ribeirão Preto, ${ }^{2}$ Coordenação \\ de Pesquisas em Produtos Naturais, Instituto Nacional de Pesquisas da Amazônia, ${ }^{3}$ Instituto de Química, \\ Universidade de São Paulo
}

*Correspondence:

N. P. Lopes

Faculdade de Ciências Farmacêuticas

de Ribeirão Preto

Universidade de São Paulo

Av. do Café $s / n$

E-mail: npelopes@fcfrp.usp.br
The labelled substrates phenylalanine and phenylpropanoid Eisoeugenol were incorporated to 5-methoxy-4-O-methyl-Eisoeugenol (E-isoelemicin) and to the tetrahydrofuran lignan verrucosin in plantlets of Virola surinamensis (Myristicaceae).
Uniterms

- Myristicaceae

- Virola surinamensis

- E-isoelemicin

- Verrucosin

- Biosynthesis

\section{INTRODUCTION}

Myristicaceous species are very abundant trees in the Amazon rain forest with several ethnopharmacological uses associated (Romoff, Yoshida, 1997). Virola surinamensis is popularly known as "ucuúba branca" or "ucuúba de igapó" (Rodrigues, 1980) and grows in flooded areas or river banks in the Amazon Forest. Its bark resin is indicated in folk medicine for the treatment of erysipelas and the tea prepared from the leaves has been used for colic and dyspepsia (Schultes, Holmstedt, 1971). The Wãipi Indians treat malaria with inhalation of the vapor obtained from $V$. surinamensis leaves and an investigation of antimalarial activity in its essential oil was carried out and nerolidol was evidenced as the active principle against Plasmodium falciparum. The mechanism of action involved the inhibition of the glycoprotein biosynthesis in the young trophozoite phase of the parasite (Lopes et al., 1999). Among several classes of compounds occurring in $V$. surinamensis, lignans and neolignans showed to be the most important, due to the diversity of biological activities displayed (Romoff, Yoshida, 1997) specially as antiparasite compounds. The neolignans virolin and surinamensin (benzodioxan derivatives), isolated from the leaves of $V$. surinamensis, showed activity against penetration of Schistosoma mansoni cercaria (Barata et al., 1978). The tetrahydro- furan lignan veraguensin (Figure 1, 6) and grandisin (7a) were isolated, from the twig extracts, as the active compounds against the trypomastigote form of Trypanosoma cruzi (Lopes et al., 1988). V. surinamensis represents an important source of such lignoids (Lopes et al., 1996) for biological and biosynthetic studies. A detailed phytochemical analysis indicated the accumulation of $\gamma$-lactones and representatives of aryltetralin and tetrahydrofuran lignans (Lopes, 1997).

The formation of lignan/neolignan by dimerization of phenylpropanoid was hypothesized a long time ago, but only recently experimental evidence has emerged. The stereoselective coupling of coniferyl alcohol leading to $(+)$-pinoresinol and its subsequent reductions to $(+)$ lariciresinol and (-)-secoisolariciresinol have been demonstrated in Forsythia species (Davin et al., 1997; Dinkova-Kostova et al., 1996). The post-coupling modifications involved in the methylenedioxyphenyl formation, a high level of specificity toward $(+)$ pinoresinol to produce $(+)$-piperitol, $(+)$-sesamin and $(+)$ sesamolin has been observed in Sesamun indicum seeds (Kato et al., 1998).

The existence of a related enzyme involved in the formation of different lignan or neolignan skeletal types found in the seeds and leaves of $V$. surinamensis which contains virolin/surinamensin (8.0.4'), veraguensin/ galbelgin $\left(8.8^{\prime}, 7.0 .7^{\prime}\right)$ and also aryltetralins $\left(8.8^{\prime}, 2.7^{\prime}\right)$ 
lignans (Lewis et al., 1995). The structural possibilities which arises from different mode of coupling of phenylpropanoid precursor followed by further modifying rearrangements give rise to a large number of lignoids in Myristicaceae as can be seen in several Virola species (Romoff, Yoshida, 1997; Kato 1995).

Due to the lack of biosynthetical data, the accepted definition of neolignans has been a matter of controversy. The current definition consider neolignans as dimers of phenylpropanoids linked by other positions than $\beta$ carbons. Neolignans were previously considered as dimers of propenyl- or allylphenols regardless the mode of coupling (Gottlieb, Yoshida, 1989). Although the expression of the secondary metabolites in the seedlings of $V$. surinamensis is directed towards the production and accumulation of $\gamma$-lactones, the phenylpropanoid $E$ isoelemicin and the neolignans veraguensin and verrucosin were also detected (Lopes et al., 1994). Thus, the aim of this paper is to describe the biosynthetic investigation carried out in plantlets of $V$. surinamensis using several putative precursors in order to evaluate their incorporation into the major tetrahydrofuran lignans.

\section{MATERIAL AND METHODS}

\section{Material}

\section{Plant material}

Plantlets of $V$. surinamensis were obtained by germination of seeds collected at Combú Island, Pará State, Brazil. Seeds were germinated using sand as substrates and maintained in greenhouse facilites at Instituto de Química/Universidade de São Paulo.

Reagents. Labelled [U- $\left.{ }^{14} \mathrm{C}\right]$ phenylalanine (Lot. 5337149 specific radioactivity $456 \mathrm{mCi} / \mathrm{mmol}$ ), $\mathrm{NaB}^{3} \mathrm{H}_{4}$ (specific radioactivity $8.8 \mathrm{Ci} / \mathrm{mmol}$ ) were purchased from ICN and $E$-isoelemicin.

\section{Apparatus}

HPLC was performed on a HP-1050 liquid chromatograph using reverse phase column (Alltech, Econosil $\left.\mathrm{C}_{18}, 250 \times 4.6 \mathrm{~mm}, 10 \mu \mathrm{m}\right)$. All samples were filtered (Acro LC 3A disposable filter, German Sciences, $0.45 \mu \mathrm{m}$ ) prior to HPLC analyses. Elution conditions at a flow rate of $0.8 \mathrm{~mL} \cdot \mathrm{min}^{-1}$, consisted of a gradient solvent system with $\mathrm{MeCN}-3 \%$ HOAc in $\mathrm{H}_{2} \mathrm{O}(65: 35)$ at $\mathrm{t}=0$ min to $\mathrm{t}=40 \mathrm{~min}(9: 1)$ and the detection was performed at $1_{\text {max }}$ $280 \mathrm{~nm}$. Chiral separations were performed on Chiral OD$\mathrm{H}$ column (150x4.6 mm, $10 \mathrm{~mm})$ using hexane:EtOH $(97: 3)$ at flow rate of $1 \mathrm{~mL} \cdot \mathrm{min}^{-1}$. Radiochemical elution profiles were measured with the Radiomatic Flo-One-
Beta radioactivity detector using eluent Flo-Scint II (Radiomatic liquid scintillation cocktail) in a 1:4 (v:v) ratio. All other radioactive samples were analysed in Ecolume (ICN Biochemicals) and measured using a liquid scintillation counter (Packard, tri-carb 2000 CA).

\section{Methods}

\section{Synthesis of labelled E-coniferyl alcohol}

Coniferyl alcohol was prepared from coniferyl aldehyde by tritiated sodium borohydride reduction as described in the literature (Ludley, Ralph, 1996).

\section{Synthesis of labelled E-isoeugenol}

To a solution of $n$ - BuLi ( $4 \mathrm{mmol}$ in hexane) at room temp. under $\mathrm{N}_{2}$ atmosphere. $N, N, N^{\prime}, N^{\prime}$-tetramethylethylenediamine ( $4 \mathrm{mmol}$ ) was added and the mixture was left for $30 \mathrm{~min}$. Then $E$-isoeugenol ( $1 \mathrm{mmol})$ was added and stirred for additional $40 \mathrm{~min}$, followed by addition of ${ }^{2} \mathrm{H}_{2} \mathrm{O}$ $(500 \mu \mathrm{L})$. The reaction mixture was neutralized with dil. $\mathrm{HCl}$ and partitioned between $\mathrm{EtOAc} / \mathrm{H}_{2} \mathrm{O}$. The organic phase was washed with brine sol. and dried over $\mathrm{Na}_{2} \mathrm{SO}_{4}$ The solvent was evaporated in vacuo and the crude material was submited to prep-TLC to afford $E$ - $\left[{ }^{2} \mathrm{H}\right]$ isoeugenol $(84 \mathrm{mg})$. The same procedure was repeated using ${ }^{3} \mathrm{H}_{2} \mathrm{O}(2.0 \mathrm{mCi} / \mathrm{mmol})$ to afford $E$ - $\left[{ }^{3} \mathrm{H}\right]$-isoeugenol $(1.0 \mathrm{mCi} / \mathrm{mmol})$.

$E$ - $\left[{ }^{2} \mathrm{H}\right]$-isoeugenol. MS $m / z(\%): 167([\mathrm{M}+3], 1.3)$, $166([\mathrm{M}+2], 10.5), 165([\mathrm{M}+1], 45), 164\left(\left[\mathrm{M}^{+}\right], 22.9\right) ;{ }^{2} \mathrm{H}$ NMR $\left(\mathrm{CDCl}_{3}\right): \mathrm{d} 1.90\left(10{ }^{2} \mathrm{H}\right), 6.92\left(3{ }^{2} \mathrm{H}\right), 6.04\left(1{ }^{2} \mathrm{H}\right)$.

\section{Feeding experiments}

Two years old plantlets of $V$. surinamensis were removed from the pots and washed. Solutions of $\left[\mathrm{U}-{ }^{14} \mathrm{C}\right]$ phenylalanine dissolved in $\mathrm{H}_{2} \mathrm{O}(4 \mathrm{mCi}, 20 \mathrm{~mL})$ and $E$ $\left[{ }^{3} \mathrm{H}\right]$-isoeugenol dissolved in DMSO $(4 \mathrm{mCi}, 10 \mathrm{~mL})$ were directly applied to the roots with a pipette. Finaly, $\mathrm{H}_{2} \mathrm{O}$ was applied to carry the remaining precursors. When uptake was complete $(8-10 \mathrm{hr}$ ), the seedlings (seven in each experiment) were replanted and kept for 7,15 or 30 days under greenhouse conditions. After each period the leaves were removed from the sand, crushed in a mortar under liquid $\mathrm{N}_{2}$ and extracted with $\mathrm{MeOH}$. The extracts were fractionated as described for the adult leaves and the fractions containing $E$-isoelemicin and verrucosin were purified by prep-TLC using hexane- $\mathrm{Me}_{2} \mathrm{CO}(4: 1)$ and $\mathrm{CHCl}_{3}-\mathrm{Me}_{2} \mathrm{CO}$-isoPrOH (95:4:1), respectively.

\section{RESULTS AND DISCUSSION}

The in vivo feeding experiments were carried out 
using plantlets of Virola surinamensis having $\left[\mathrm{U}-{ }^{14} \mathrm{C}\right]$ phenylalanine, $E$ - $\left[9-{ }^{3} \mathrm{H}_{2}\right]$-coniferyl alcohol, and $E-\left[{ }^{3} \mathrm{H}\right]$ isoeugenol as substrates. The evaluation of incorporations were determined by HPLC-RP coupled to liquid scintillation detector for radiochemical analysis or by purification followed by NMR analysis when deuterated $E$ isoeugenol was used as substrate. The administration of [U${ }^{14} \mathrm{C}$ ] phenylalanine yielded $0.02 \%$ of incorporation in the phenylpropanoid $E$-isoelemicin (4) after 7 days. In case of neolignan verrucosin (5), 30 days of incubation were required (Table I, Figure 1). In both experiments $E$ isoelemicin and verrucosin were purified from the crude extracts obtained from leaves and stems by prep-TLC on silica-gel and identified based on their ${ }^{1} \mathrm{H}$ NMR data and by comparison of their retention time on HPLC-RP coupled to liquid scintillation detector. The radiation in the fractions

TABLE I - Incorporation of $\left[\mathrm{U}-{ }^{14} \mathrm{C}\right]$ phenylalanine and $E-\left[{ }^{3} \mathrm{H}\right]$-isoeugenol into $E$-isoelemicin (4) and verrucosin (5).

\section{Precursor (incubation days)}

$\left[\mathrm{U}-{ }^{14} \mathrm{C}\right]$-phenylalanine (7)

$\left[\mathrm{U}-{ }^{14} \mathrm{C}\right]$-phenylalanine (15)

$\left[\mathrm{U}-{ }^{14} \mathrm{C}\right]$-phenylalanine (30)

$\left[{ }^{3} \mathrm{H}\right]$ - $E$-isoeugenol (30)
Absolute incorporations (\%)

\section{$E$-isoelemicin}

verrucosin

$\begin{array}{cc}0.02 & \text { ND } \\ 0.13 & \text { ND } \\ 0.8 & 0.09 \\ - & 0.012\end{array}$

ND: Not detected.

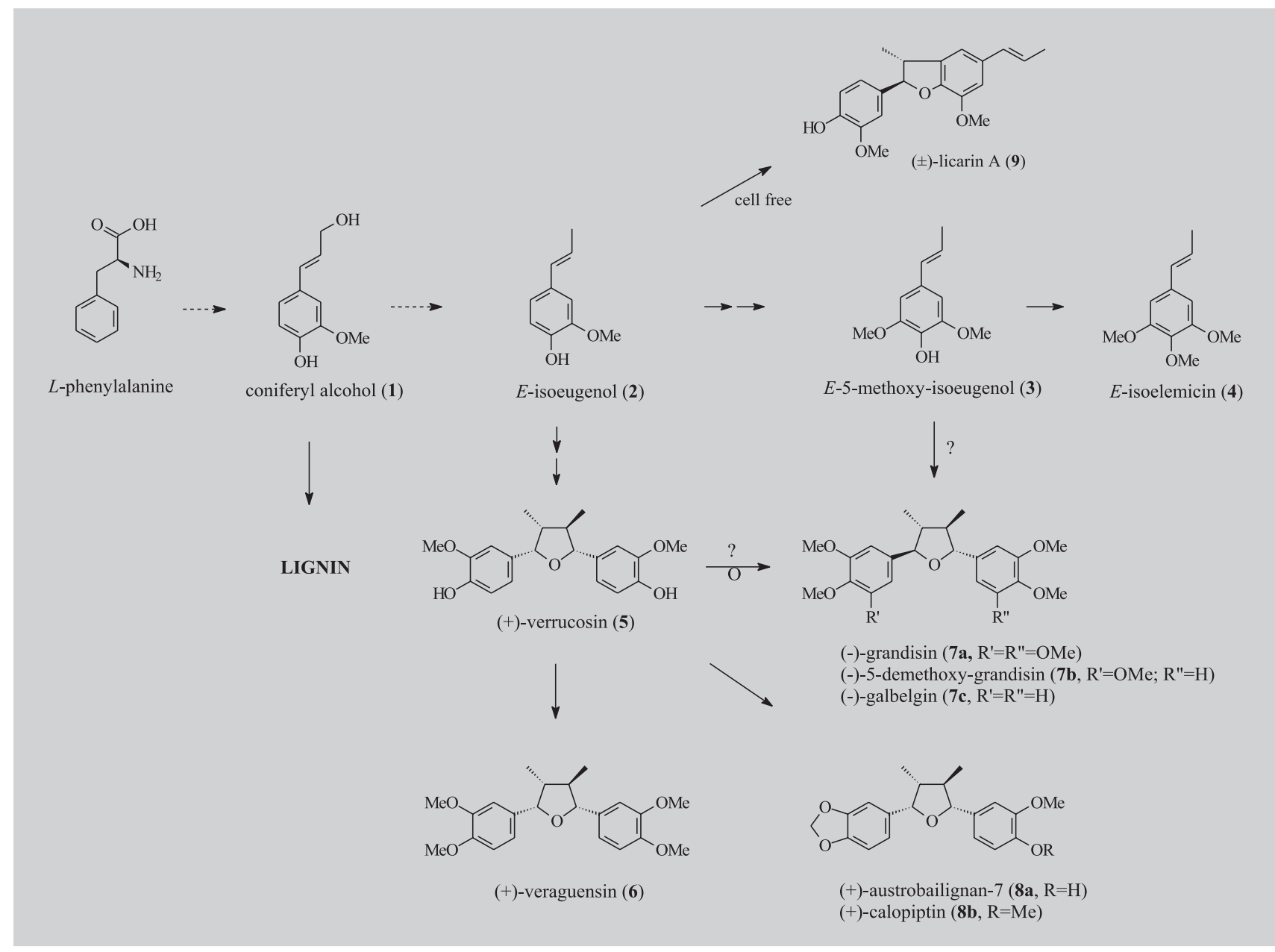

FIGURE 1 - Biosynthetic relationship between phenylpropanoid and tetrahydrofuran lignans in $V$. surinamensis. 
corresponding to $E$-isoelemicin and verrucosin were determined by scintillation countings of the solutions.

The incorporation of $\left[\mathrm{U}-{ }^{14} \mathrm{C}\right]$ phenylalanine to $E$ isoelemicin could be observed after 7 days $(0.02 \%)$ and reach $0.8 \%$ after 30 days when it was also possible to detect incorporation to verrucosin. No detectable radiation in these compounds was observed using $E-\left[9-{ }^{3} \mathrm{H}_{2}\right]$-coniferyl alcohol $(4 \mathrm{mCi})$ even after 30 days of incubation. In spite of the coniferyl alcohol is placed closer to the key steps of $E$ isoelemicin and verrucosin biosynthesis than phenylalanine, the lack of its incorporation is not surprising because coniferyl alcohol can be directly incorporated to lignin biosynthesis. Additionally, the translocation of coniferyl alcohol to the appropriate compartment in which verrucosin biosynthesis takes place, should be impaired since this phenolic phenylpropanoid could be consumed by peroxidases or laccases to lignin or be trapped by protein complexation as well.

The phenylpropanoid $E$-isoeugenol was labelled under treatment with $\mathrm{n}$-BuLi followed by quenching with the resulting anion with $\mathrm{D}_{2} \mathrm{O}$. The product was analysed by mass spectrometry which indicated the predominance of monodeuterated isoeugenol. Analysis of the ${ }^{2} \mathrm{H}$ NMR spectrum indicated the presence of deuterium in the methyl group $\left({ }^{2} \mathrm{H}-9\right)$, aromatic ring $\left(\mathrm{Ar}^{2}{ }^{2} \mathrm{H}\right)$ and olefinic methyne $\left({ }^{2} \mathrm{H}-8\right)$ with a relative distribution of $10 / 3 / 1$ as measured by the signal integration. The administration of $E$ - $\left[{ }^{3} \mathrm{H}\right]$-isoeugenol $(1.0 \mathrm{mCi} / \mathrm{mmol})$ obtained using ${ }^{3} \mathrm{H}_{2} \mathrm{O}$ (see Experimental) resulted in a relatively low, but consistent level of incorporation to the tetrahydrofuran lignan verrucosin (5) (Table I), but no conversion to $E$ isoelemicin could be observed. An attempt to investigate the consume of coniferyl alcohol and $E$-isoeugenol by peroxidases, the soluble and insoluble fractions obtained from leaves, roots and stems were incubated with these substrates. In both cases, the HPLC profile of the resulting extracts were similar to that obtained by conversion using horseradish peroxidase. When $E$-isoeugenol was used as substrate the major compound produced was identified as the dihydrobenzofuran neolignan licarin $\mathrm{A}(9)$ (Wenkert et al., 1976). The analysis of this product by chiral chromatography revealed the formation of racemic mixture as expected for non enantioselective enzyme such as peroxidases.

This set of results showed the dimerization of $E$ isoeugenol into the lignan verrucosin $(\mathbf{5})$ which should be involved as a key intermediate in the biosynthesis of veraguensin (6) and other compounds in $V$. surinamensis (Figure 1). The biosynthesis of highly oxygenated tetrahydrofuran lignans such as grandisin (7a) should require the $E$-5-methoxy-isoeugenol (3) as direct precur- sor. So far, the biosynthetic studies of either lignans and neolignans in woody plants such as $V$. surinamensis has been precluded by slow growth rate and formation of products. A similar study involved Piper regnellii in which the incorporation of $\left[\mathrm{U}-{ }^{14} \mathrm{C}\right]$ phenylalanine to the major dihydrobenzofuran neolignans (Sartorelli et al., 2001) took place in few minutes. Additionally, an enzyme fraction converted enantioselectively the monomer $p$ hydroxypropenylbenzene into $(+)$-conocarpan.

\section{ACKNOWLEDGMENTS}

This work was supported by grants provided by Fundação de Amparo à Pesquisa do Estado de São Paulo and Programa de Apoio ao Desenvolvimento Científico e Tecnológico (PADCT). The authors are indebted to $\mathrm{CNPq}$ for fellowships provided.

\section{RESUMO}

\section{Biossíntese de lignanas tetraidrofurânicas em Virola surinamensis}

Através de experimentos de administração in vivo em plântulas de Virola surinamensis, observaram-se as incorporações de fenilalanina e do fenilpropanóide Eisoeugenol no 4-O-metil-5-metoxi-E-isoeugenol (Eisoelemicina) e na lignana tetraidrofurânica verrucosina.

UNITERMOS: Myristicaceae. Virola surinamensis. Eisoelemicina. Verrucosina. Biossintese.

\section{REFERENCES}

BARATA, L. E. S.; BAKER, P. M.; GOTTLIEB, O. R.; RÚVEDA, E. A. Neolignans of Virola surinamensis. Phytochemistry, Oxford, v.17, n.4, p.783-785.1978.

DAVIN, L. B.; WANG, H. B.; CROWEL, A. L.; BEDGAR, D. L.; SARKANEN, S., LEWIS, N. G. Stereoselective bimolecular phenoxy radical coupling by an auxiliary (dirigent) protein without an active center. Science, Washington, v.275, n.5298, p.362-366, 1997.

DINKOVA-KOSTOVA, A. T.; GANG, D. R.; DAVIN, L. B.; BEDGAR, D. L.; CHU, A., LEWIS, N. G. (+)Pinoresinol/(+)-lariciresinol reductase from Forsythia intermedia. Protein purification, cDNA cloning, heterologous expression and comparision to isoflavone reductase. J. Biol. Chem., Bethesda, v.271, n.46, p.2947329482, 1996. 
GOTTLIEB, O. R.; YOSHIDA, M. Natural Products of Woody Plants.In: ROWE, J. W. Chemicals Extraneous to the lignocellulosic Cell Wall. Berlin: Springer Verlag, 1989. p. 439-511.

KATO, M. J. The Chemistry of Amazonian Myristicaceae: developmental, ecological and pharmacological aspects. In: SEIDL, P. R.; GOTTLIEB, O. R.; KAPLAN, M. A. C. Chemistry of the Amazon: Biodiversity, natural products and environmental issues., Washington: American Chemical Society, 1995. v.588, p. 168-179 (Symposium Series).

KATO, M. J.; CHU, A.; DAVIN, L. B.; LEWIS, N. G. Biosynthesis of antioxidant lignans from Sesamum indicum. Phytochemistry, Oxford, v.47, n.4, 583-591, 1998.

LEWIS, N. G., KATO, M. J., LOPES, N. P., DAVIN, L. B. Lignans: Diversity, biosynthesis, and function. In: SEIDL, P. R.; GOTTLIEB, O. R.; KAPLAN, M. A. C. Chemistry of the Amazon. Washington: American Chemical Society, 1995. v. 588, p. 135-167 (Symposium Series).

LOPES, N. P.; FRANÇA, S. C. F.; PEREIRA, A. M. S.; MAIA, J. G. S.; KATO, M. J.; CAVALHEIRO, A. J.; GOTTLIEB, O. R.; YOSHIDA, M. The chemistry of Brazilian Myriticaceae. 36. A butenolide from seedlings and micropropagated leaves of Virola surinamensis. Phytochemistry, Oxford, v. 35, n.6, p.1469-1470, 1994.

LOPES, N. P.; CHICARO, P.; KATO, M. J.; ALBUQUERQUE, S.; YOSHIDA, M. Flavonoids and lignans from Virola surinamensis twigs and their in vitro activity against Trypanosoma cruzi. Planta Med., Stuttgart, v.64, n.7, p.667-669, 1988.

LOPES, N. P.; BLUMENTHAL, E. E. A.; CAVALHEIRO, A. J.; KATO, M. J., YOSHIDA, M. Lignans, -lactones and propiophenones of Virola surinamensis. Phytochemistry, Oxford, v.43, n.5, p.1089-1092, 1996.
LOPES, N. P. Metabólitos secundários de Virola surinamensis (Rol.) Warb. (Myristicaceae). São Paulo, 1997. 68p. [Tese de Doutorado. Instituto de Química da Universidade de São Paulo].

LOPES, N. P.; KATO, M. J.; ANDRADE, E. H. A.; MAIA, J. G. S.; YOSHIDA, M., PLANCHART, A. R.; KATZIN, A. M. Antimalarial use of volatile oil from leaves of Virola surinamensis (Rol .) Warb. By Waiaipi Amazon Indians. J. Ethnopharmacol., Lausanne, v.67, n.3, p.313-319, 1999.

LUDLEY, F. H.; RALPH, J. Improved preparation of coniferyl and sinapyl alcohols. J. Agric. Food Chem., Washington, v.44, n.10, p.2942-2943, 1996.

SARTORELLI, P.; BENEVIDES, P. J. C.; ELLENSOHN, R. M.; ROCHA, M. V. A., F.; MORENO, P. R. H.; KATO, M. J. Enantioselective conversion of $p$ hydroxypropenylbenzene to (+)-conocarpan in Piper regnellii. Plant Science, Limerick, v.161, n.6, p.10831088, 2001.

SCHUlTES, R. E.; HOLMSTEDT, B. Comments on poisonous plants from tropical new world.8. Miscellaneous plants of South-America. Lloydia, v.34, n.1, p.61-90, 1971.

RODRIGUES, W. Revisão taxonômica das espécies de Virola Aublet. Acta Amazonica, Manaus, v.1,. p. 1-127, 1980.

ROMOFF, P.; YOSHIDA, M. Chemical constituents from Myristicaceae. Cienc. Cultura, São Paulo, v.49, n.5/6, p.345-353, 1997.

WENKERT, E.; GOTTLIEB, H. E.; GOTTLIEB, O. R.; PEREIRA, M. O. D. S.; FORMIGA, M. D., ${ }^{13} \mathrm{C}$ NMR spectroscopy of neolignans. Phytochemistry, Oxford, v.15, n.10, 1547-1551, 1976.

Recebido para publicação em 15 de maio de 2003. 